\title{
PENERAPAN METODE SCRUM DAN VIRTUAL PRIVATE NETWORK DALAM PERANCANGAN SISTEM ORDERSALES
}

\section{IMPLEMENTING SCRUM METHODOLOGY AND VIRTUAL PRIVATE NETWORK IN SALES ORDERING SYSTEM DESIGN}

\author{
Tony Wijaya \\ Jurusan Sistem Informasi STMIK Pontianak \\ Jl. Merdeka No. 372 Pontianak, Kalimantan Barat \\ E-mail: mail.tonywijaya@gmail.com
}

Diterima: 4 Januari 2018/ Disetujui : 22 Januari 2018

\begin{abstract}
Sales Ordering System is a mobile application used by salesman to create sales invoice. With this system, salesman can directly input invoices to server computer at head office using their smartphones. It is possible because there is Virtual Private Network (VPN) that connect server PC with those smartphones. This system has featureof sales invoice which can be done using smartphone browser.The writer implements Scrum which is derived from Agile Methodology in this research to design the system.Scrum is a framework that focus at dividing main goal into several easy-to-achieve goals.Scrum assumed user requirements in a project development cannot be listed completely up front, because they often changed their minds in the process.Testing is done with blackbox method to ensure the feature mentioned above is well implemented. With sales ordering system, companies can achieve one step further in productivity and to give better service and satisfaction to consumer.
\end{abstract}

Keywords : Scrum, Sales Ordering System, VPN.

\begin{abstract}
ABSTRAK
Sistem Order Sales merupakan aplikasi mobile yang digunakan oleh para salesman untuk membuat order penjualan. Dengan sistem ini, para salesman bisa langsung melakukan input penjualan ke server di kantor pusat melalui smartphone. Hal ini dimungkinkan karena antara smartphone dan server di kantor pusat telah terhubung melalui koneksi Virtual Private Network (VPN).Sistem ini memiliki fitur pembuatan sales order baru yang dilakukan melalui browser smartphone.Untuk merancang system ini, penulis mengimplementasikan metodologi Agile dengan pendekatan Scrum. Scrum merupakan sebuah kerangka kerja yang memfokuskan pada pembagian goal utama menjadi goal-goal kecil yang mudah dicapai. Scrum juga berasumsi bahwa sebuah project pengembangan aplikasi tidak dapat digambarkan secara menyeluruh pada awal pelaksanaan project, karena pemakai akhir biasanya berubah pikiran sejalan dengan proses pengembangan aplikasi. Pengujian dilakukan dengan metode blackbox untuk memastikan fitur yang dituliskan di atas sudah tercapai.Dengan adanya sistem order sales, perusahaan akan selangkah lebih maju dalam meningkatkan produktivitas kerja serta meningkatkan pelayanan dan kepuasan pelanggan.
\end{abstract}

Kata kunci : Scrum, Sistem Order Sales, VPN. 


\section{PENDAHULUAN}

Teknologi mobile sudah bukan sesuatu yang asing lagi bagi kita, baik di pusat kota maupun daerah pedalaman di Indonesia. Hal ini didukung oleh pasar global yang mampu menyuplai gadgetgadget seperti smartphone dan tablet sampai ke seluruh pelosok negeri. Perkembangan infrastruktur komunikasi di Indonesia pun menjadi salah satu faktor yang membuat fitur-fitur teknologi ini bisa berfungsi dengan baik. Dampaknya kepada masyarakat kita juga cenderung positif, yaitu lebih dari 100 juta penduduk Indonesia sudah aktif menggunakan teknologi mobile [1].

Penulis melihat fakta tersebut sebagai peluang yang harus dimanfaatkan oleh perusahaan, terutama yang bergerak di bidang distribusi. Teknologi mobile dapat dimanfaatkan oleh perusahaan untuk menerapkan sistem order sales yang memungkinkan para salesman membuat sales order langsung melalui smartphone atau tablet yang mereka bawa. Mereka tidak perlu lagi mencatat orderan di buku atau memo dan kembali ke kantor untuk membuat orderan. Hal ini sudah sangat membantu perusahaan meningkatkan efisiensi dalam hal operasional perusahaan.

Satu hal yang istimewa dari aplikasi mobile adalah kemampuan akses dari mana saja. Hal ini juga penulis terapkan dalam sistem order sales di dalam penelitian ini. Sistem ini dapat diakses dari kantor, luar kantor, luar kota, dan bahkan luar negeri, apabila diperlukan. Arsitektur jaringannya menggunakan layanan Virtual Private Network (VPN), yaitu sebuah layanan yang memperluas jaringan LAN dengan memanfaatkan jaringan publik seperti Internet [2]. Dengan VPN, dapat tercipta koneksi antara smartphone salesman dengan computer server di kantor pusat melalui perantara koneksi Internet. Waupun memanfaatkan jaringan Internet, namun VPN tidak dapat diakses secara publik karena layanan VPN mampu menciptakan sebuah tunnel yang mengisolasikan diri menjadi jaringan privat (LAN).

Dalam merakayasa sebuah perangkat lunak, diperlukan metode perancangan perangkat lunak dan pendekatan yang tepat sesuai dengan kebutuhan. Metode perancangan perangkat lunak yang diterapkan oleh penulis di sini adalah Agile dengan pendekatan Scum. Scrum merupakan sebuah kerangka yang digunakan untuk mengelola proyek-proyek perangkat lunak yang bersifat fleksibel atau tangkas (agile), yang sudah mendapat sorotan di dalam pasar perangkat lunak untuk menyediakan fleksibilitas kepada tim pengembang [3]. Penulis memilih metode ini karena di dalam merekayasa perangkat lunak ini, penulis tidak dapat menggambarkan keseluruhan kebutuhan (requirement) pada awal tahap pengembangan. Seiring dilakukannya proses rekayasa, ditemukan beberapa perubahan kebutuhan dan hambatan yang menuntut penulis untuk melakukan perubahan terhadap rancangan awal. Oleh karena itu, metode Scrum ini sangat mendukung di dalam proses penelitian ini.

Tujuan penelitian ini adalah untuk merekayasasistem order sales sehingga dapat membantu perusahaan meningkatkan produktivitas para sales dalam melayani pelanggan. Fitur utamanya yaitu pembuatan sales order, mengelola sales order, melakukan pengecekan stok, dan melakukan setoran terhadap piutang pelanggan. Koneksi antara smartphone dan komputer di server pusat menggunakan koneksi VPN. Dengan adanya sistem order sales ini penulis berharap perusahaan dapat memaksimalkan teknologi smartphone untuk meningkatkan produktivitas para sales yang pada nantinya tentu akan meningkatkan laba perusahaan pula.

\section{METODE PENELITIAN}

Penulis merancang perangkat lunak dengan menggunakan metode perancangan perangkat lunak Agile (Agile Software Development) yang merupakan kerangka konseptual untuk mengembangkan perangkat lunak yang memperkenalkan beberapa tahapan perulangan (iterasi) selama siklus hidup sebuah proyek [4].Metode agile memiliki karakteristik ringan, skala kecil hingga menengah, kebutuhan (requirement) yang samar dan/atau sering berubah, perancangan yang sederhana, hingga sistem yang minimal untuk menyelesaikan proyek. Setiap programmer yang menggunakan metode ini menjunjung nilai berupa: 
- Mengedepankan individu dan interaksi daripada proses dan alat

- Mengedepankan perangkat lunak yang berfungsi sesuai kebutuhan daripada dokumentasi yang lengkap

- Mengedepankan kolaborasi dengan pelanggan daripada negosiasi kontrak

- Mengedepankan respon terhadap perubahan daripada mengikuti rancangan

Scrummerupakan metodologi perancangan perangkat lunak dengan pendekatan iteratif dan inkrementaluntuk menyaring hal-hal yang dapat diprediksi dan mengontrol kerusakan akibat kesalahan rancangan awal [3]. Dalam kerangka ini diperlukan 3 (tiga) fungsi penting:

1. Product Owner (PO) atau pemilik produk, merupakan seorang profesional yang memiliki pengetahuan yang mendalam mengenai produk yang akan direkayasa.

2. Scrum Teamatau tim scrum, yang beranggotakan indvidu-individu yang mampu mengoranisasikan dirinya sendiri dan merupakan sebuah tim multi-fungsi.

3. Scrum Master, adalah orang yang bertanggung jawab untuk mengarahkan tim Scrumsupaya bekerja menuju arah dan tujuan yang benar dan mengatasi semua rintangan dan halangan yang dapat mempengaruhi kinerja mereka.

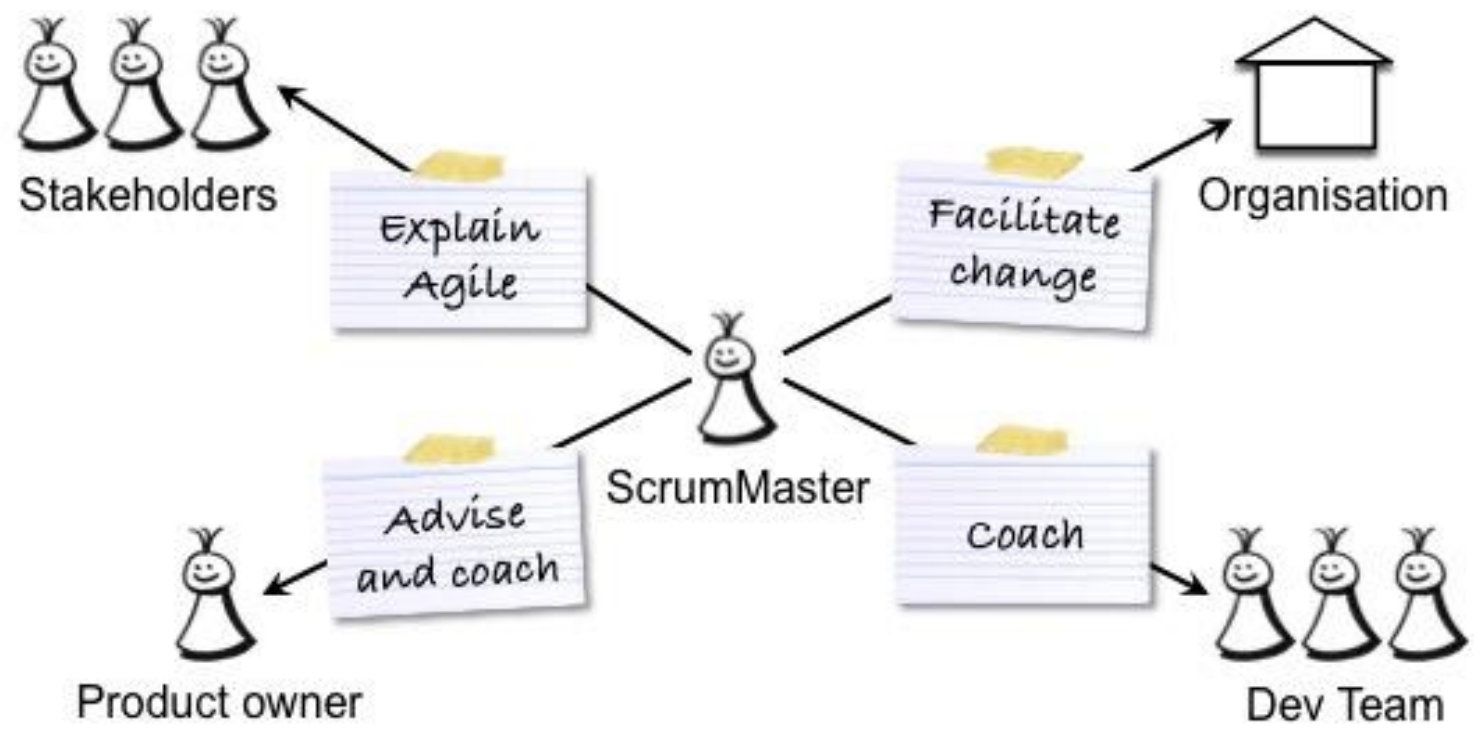

Gambar 1. Fungsi-fungsi Scrum.

Ketiga fungsi ini bekerja dalam proses pengembangan yang konstan dan lingkaran interaksi yang disebut Sprint. Sprint merupakan kegiatan pengembangan untuk mencapai tujuan kecil (yang dipecah-pecah dari tujuan utama) yang biasanya menggunakan waktu 2-4 minggu, yang disebut TimeBox. Di dalam sebuah Sprint, semua kebutuhan-kebutuhan (requirements) untuk mencapai tujuan kecil tersebut disebut dengan Backlog of the Product dan biasanya didefinisikan oleh PO. Pada awal Sprint, tim akan mendefinisikan Backlog of the Product dan kemudian mulai bekerja sehingga pada akhir Sprint, tim sudah menyelesaikan tujuan kecil tersebut untuk ditunjukkan kepada pelanggan (client). 


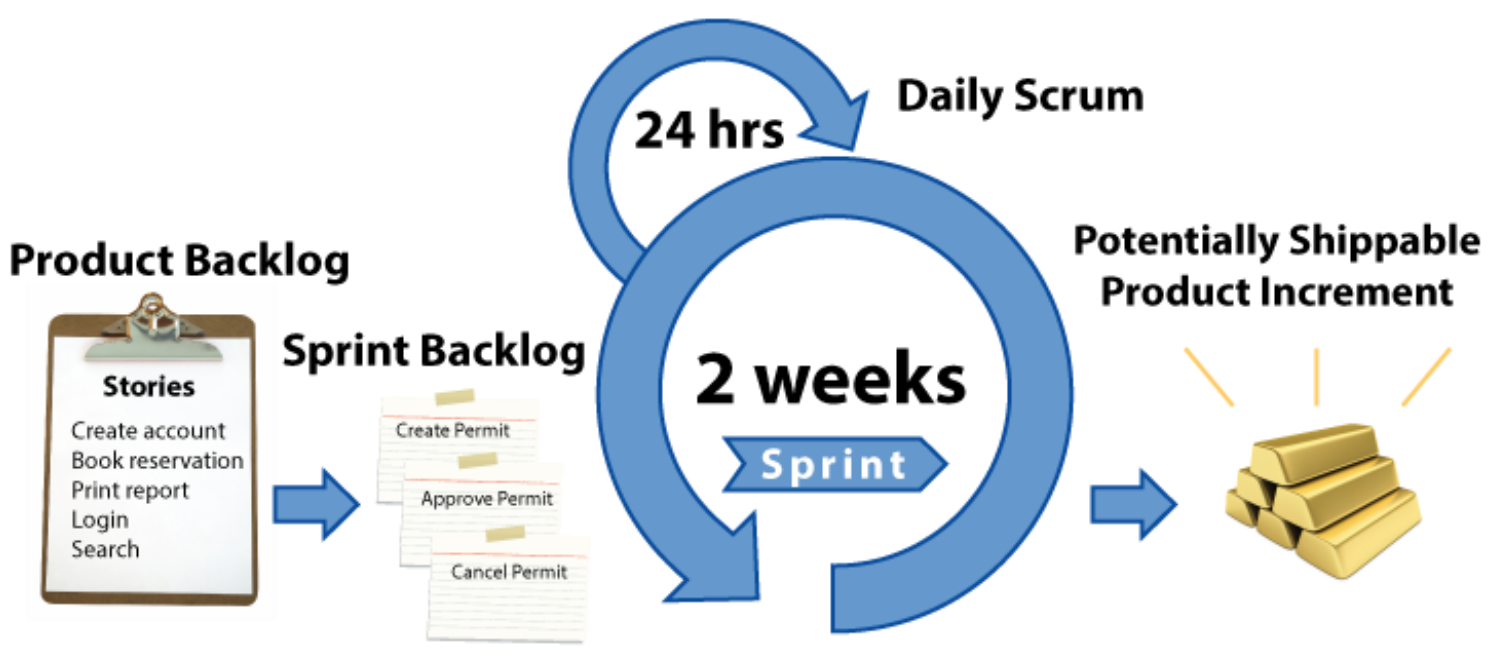

Gambar 2. Sprint dan Backlog of the Product dalam metodologi Scrum.

Microsoft Visual Studio merupakan sebuah Integrated Development Environment (IDE) dari Microsoft. IDE ini digunakan untuk mengembangkan program komputer pada sistem operasi Windows seperti situs web, aplikasi web, web service dan aplikasi desktop [5].Aplikasiini berbasis web yang dirancang, dikode, dan diuji menggunakan Visual Studio 2010.Bahasa pemrograman yang digunakan adalah bahasaC\#dan dikompilasi untuk .NET Framework versi 4.0 yang dapat dijalankan pada sistem operasi Windows XP, Windows Server 2003, Windows 7, Windows Server 2008, Windows 8, Windows Server 2012, Windows 10 dan Windows Server 2016.

Logika bisnis dan akses ke basis data tidak diletakkan pada web mobile, melainkan pada web service yang menjadi backend pada sistem order sales. Implementasi web service ini menggunakan Windows Communication Foundation (WCF) adalah kerangka kerja untuk membangun aplikasi berorientasi layanan (Service-Oriented Architecture / SOA) [6]. Web service meningkatkan kolaborasi antara pemrogram dengan perusahaan, memungkin sebuah fungsi diakses oleh aplikasi lain tanpa perlu mengetahui detil pemrograman yang terdapat dalamnya [7].

Basis data yang digunakan untuk sistem informasi dagang adalah basis data MySQL. Basis data MySQL merupakan Relational DataBase Management System (RDBMS) yang dapat digunakan untuk asplikasi berbasis web, cloud, mobile dan aplikasi embedded [8]. Sedangkan GUI tools yang digunakan untuk mengelola basis data adalah MySQL Workbench, yaitu merupakan alat grafis terpadu bagi arsitek basi data, pengembang aplikasi, dan administrator basis data. Aplikasi ini menyediakan fitur pemodelan data, pengembangan SQL, dan alat administrasi yang lengkap untuk konfigurasi server, administrasi pemakai, backup, dan lain-lain [9].

Dalam merancang antarmuka web, penulis menggunakan teknologi Asynchronous JavaScript and XML (AJAX)yang merupakan adalah seperangkat teknik pengembangan Web yang menggunakan banyak teknologi Web di sisi klien untuk membuat aplikasi Web asinkron. Dengan AJAX, aplikasi Web dapat mengirim data ke dan mengambil dari server secara asinkron (di latar belakang) tanpa mengganggu tampilan dan perilaku dari halaman yang ada [10].

\section{HASIL DAN PEMBAHASAN}

Merekayasa sebuah sistem order sales merupakan produk atau tujuan utama atau main goal pada proyek ini. Dengan menerapkan metode Scrum, maka produk tersebut dibagi menjadi5 subproyek yang dapat segera diselesaikan dalam setiap Sprint:

1. Sprint ke-1, merancang basis data.

2. Sprint ke-2, merancang web service dan logika bisnis.

3. Sprint ke-3, merancang antar-muka.

4. Sprint ke-4, menyiapkan koneksi VPN.

5. Sprint ke-5, menyatukan dan menguji produk keseluruhan. 
Pada Sprint ke-1, penulis merancang basis data dengan model seperti pada gambar 3. TimeBox yang diperlukan untuk Sprint ini adalah 2 hari. Basis data yang digunakan adalah MySQL.

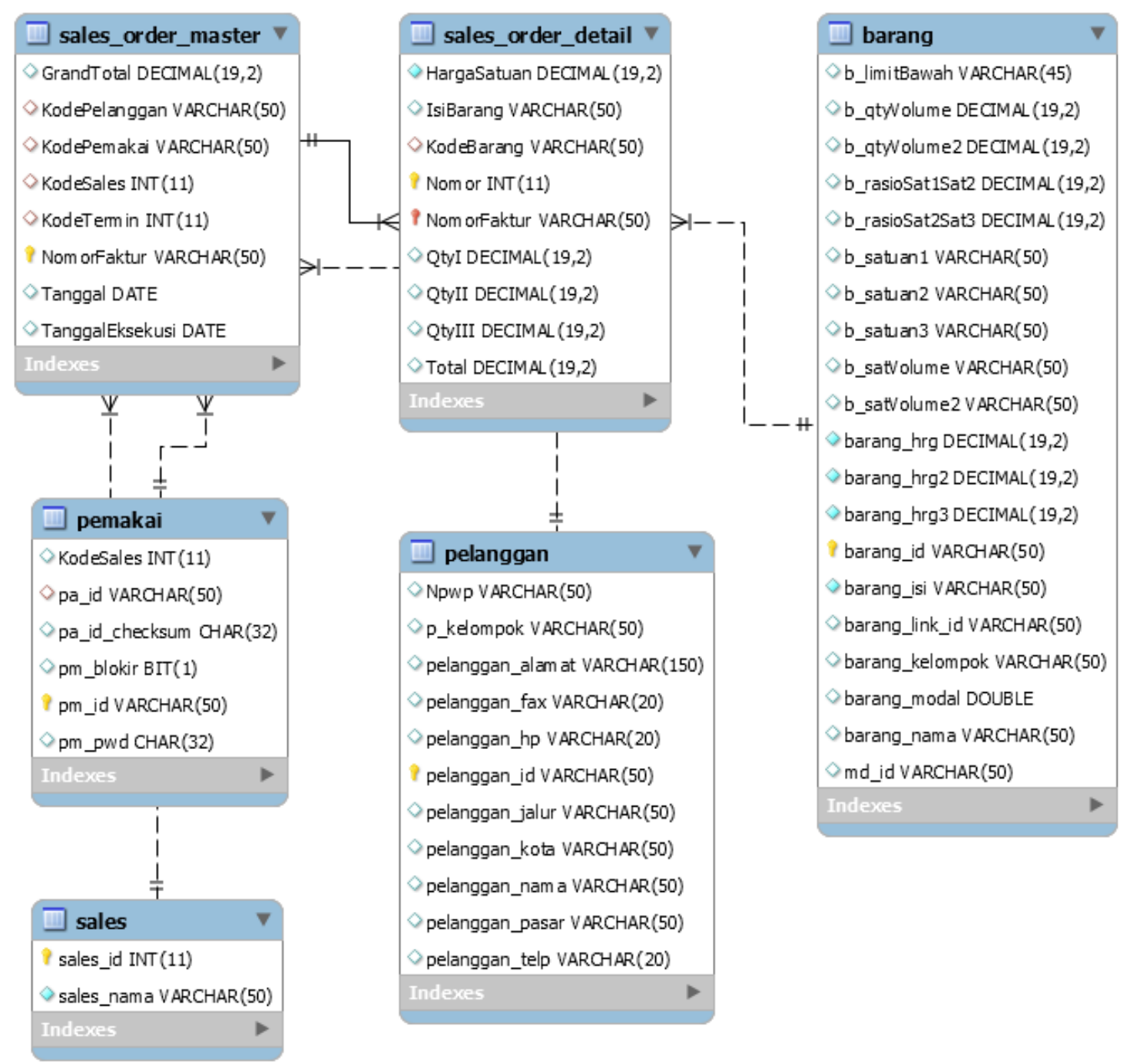

Gambar 3. Diagram hubungan entitas basis data.

Pada gambar 3, dapat dilihat bahwa terdapat 6 tabel basis data yang saling berhubungan untuk membangun sistem order sales. Diagram di atas direkayasa menggunakan MySQL Workbench.

Pada Sprint ke-2, penulis akan merancang web service dan logika bisnis. Semua logika bisnis tidak diletakkan di aplikasi web untuk mobile, melainkan di server berupa web service yang terpisah. Arsitektur aplikasi akan terlihat seperti gambar 4.

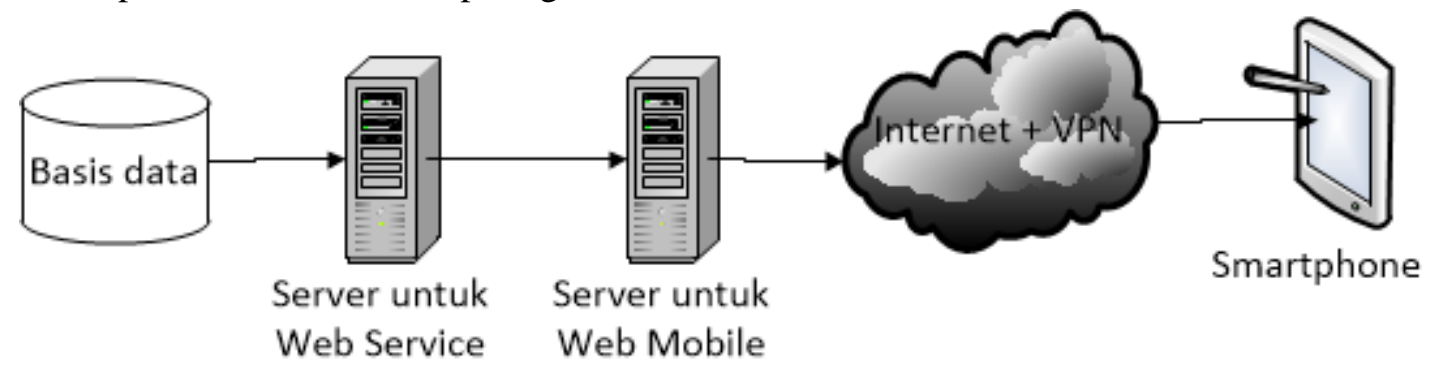

Gambar 4. Arsitektur Sistem Order Sales. 
Pada gambar 4 dapat dilihat bahwa penulis merancang aplikasi dari kiri ke kanan, yaitu mulai dari basis data, logika bisnis pada "Server untuk Web Service", tampilan antar muka pada "Server untuk Web Mobile", koneksi VPN, sampai pada pengujian di smartphone.Logika bisnis yang dirancang berupa class-class program yang ditulis dalam bahasa C\#. Class-class program inilah yang mempunyai wewenang untuk mengakses basis data karena diimplementasikan ke dalam bentuk web service. Gambar 5 menjelaskan class-class diagram pada sistem order sales:

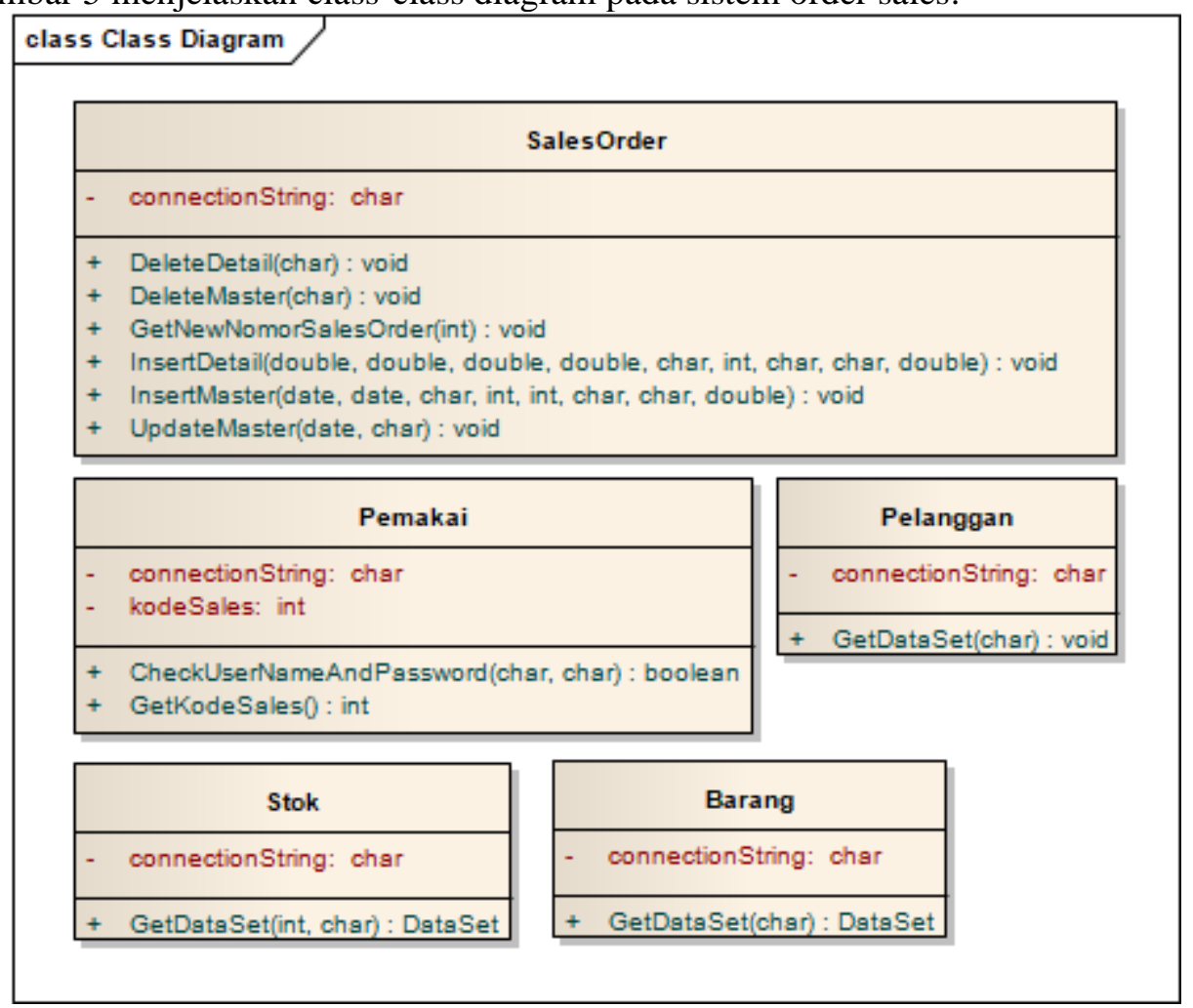

Gambar 5. Class Diagram Sistem Order Sales.

Class diagram pada gambar 5 di atas diimplementasi dengan teknologi Windows Communication Foundation (WCF) supaya dapat dipublikasi menjadi web service. Setelah dipublikasi, semua method pada class-class tersebut dapat diakses di http://192.168.192.250:8888/BbSidWcfService. Alamat tersebut bukan merupakan sebuah domain publik seperti google.com karena tidak dapat diakses secara publik. Alamat tersebut merupakan alamat PC server di kantor pusat dan dapat diakses oleh smartphone melalui koneksi VPN yang akan dijelaskan pada Sprint ke-4. TimeBox yang dibutuhkan untuk Sprint ke-2 ini adalah 4 minggu.

Pada Sprint ke-3, penulis akan merancang antar-muka web mobile yang dapat diakses oleh pemakai. Untuk menjelaskan aktor-aktor yang terlibat dalam antar-muka ini, penulis menyajikan Use Case Diagram sebagai berikut: 


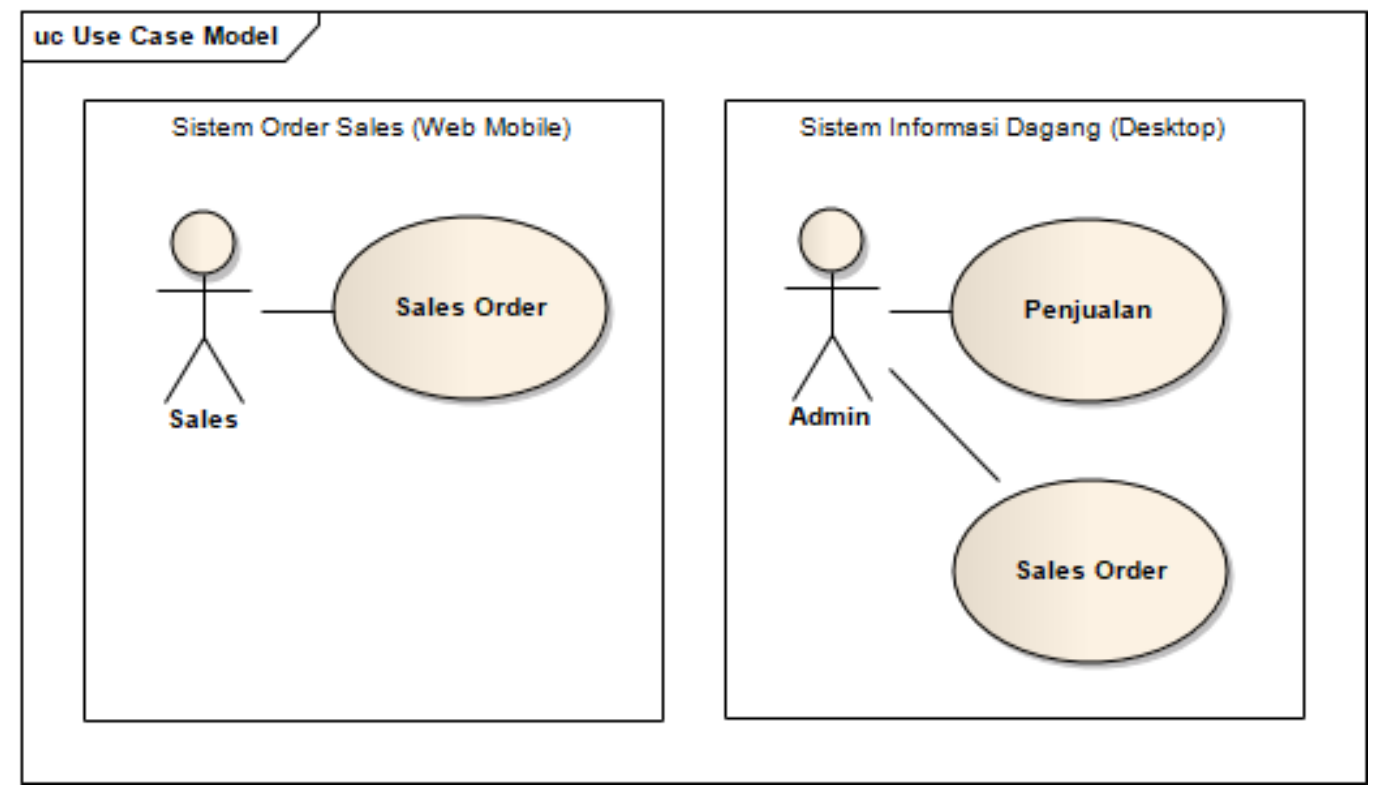

Gambar 6. Use Case Diagram Sistem Order Sales dan Sistem Informasi Dagang.

Gambar 6 menunjukkan 2 aktor yaitu sales dan admin di kantor. Sales hanya berhubungan dengan sistem order sales yang berupa web mobile. Setelah membuat faktur pada sales order, maka admin dapat mengakses menu sales order yang ada pada sistem informasi dagang versi dekstop. Dari situ admin dapat mengekspor sales order tersebut menjadi faktur penjualan. Sales order yang dibuat oleh sales tidak serta merta langsung dijadikan faktur penjualan karena harus melalui validasi oleh admin terlebih dahulu. Barang yang tidak ada cukup stok atau pelanggan yang tidak eligible dapat dibatalkan oleh admin. Ini merupakan proses bisnis yang menjadi requirement sistem pada CV. Surya Putra. TimeBox yang dibutuhkan oleh Sprint ke-3 ini adalah 2 minggu. 


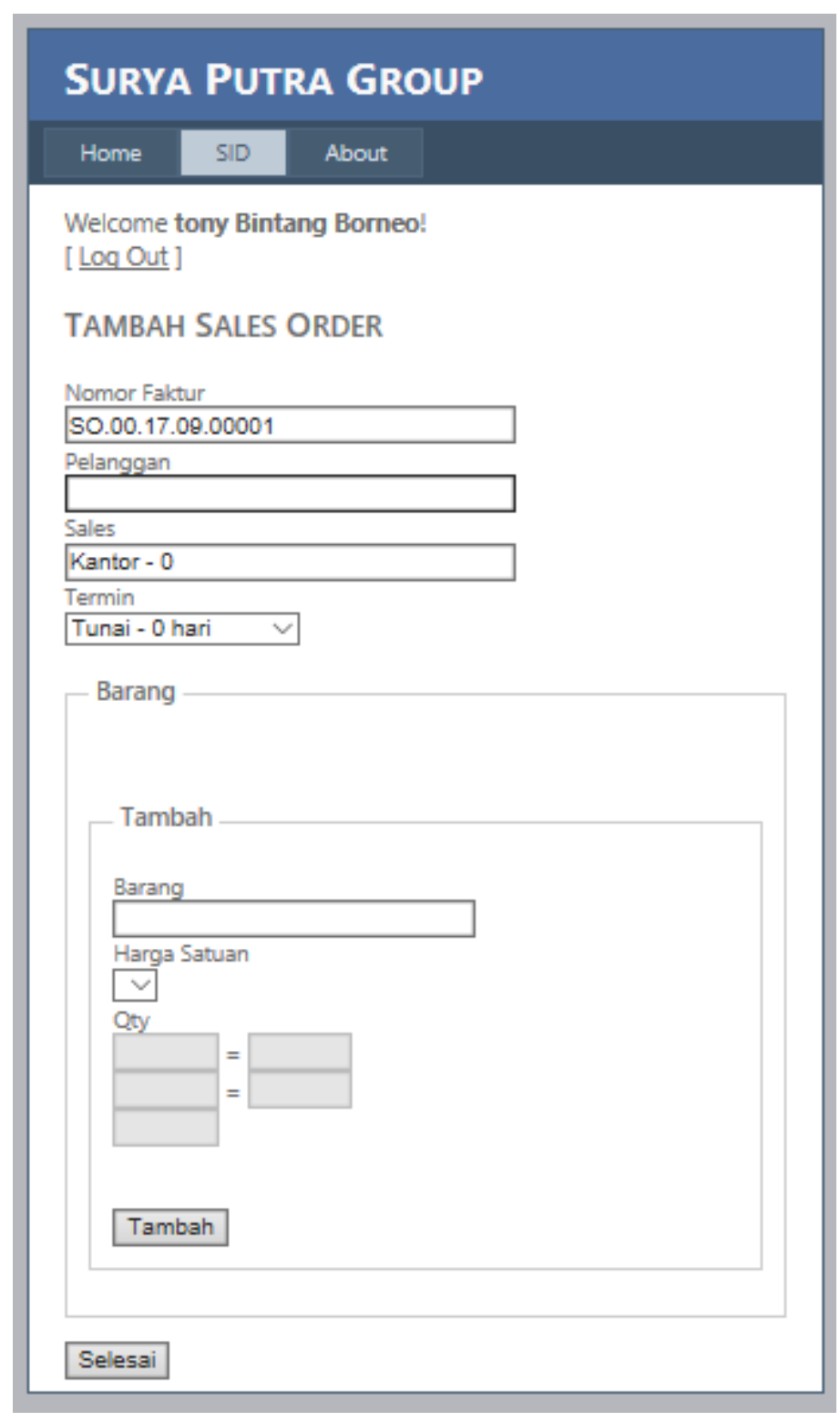

Gambar 7. Hasil rancangan antarmuka "Tambah Sales Order".

Hasil rancangan antarmuka order sales baru dapat dilihat pada gambar 7. Nomor faktur digenerate secara otomatis oleh sistem dan tidak bisa diubah manual oleh sales. Pelanggan dipilih dengan memasukkan minimal 3 karakter. Kemudian dengan bantuan AJAX, halaman web akan menampilkan daftar pelanggan yang cocok dengan kata kunci tandi. Penulis menggunakan AJAX karena proses pengambilan data dilakukan secara asynchronous sehingga tidak perlu berpindah halaman. Demikian juga dengan barang, dipilih dengan AJAX, yang kemudian akan meng-update harga satuan dan qty yang diinginkan. Harga satuan tidak dapat dipilih oleh sales, melainkan cukup memilih dari 3 harga satuan yang sudah disediakan. Setelah sales memilih barang yang ingin ditambahkan, sales kemudian meng-klik tombol "Tambah" dan AJAX akan mengirimkan data tersebut ke web service untuk diproses ke dalam tabel basis data yaitu tabel "sales_order_master" dan "sales_order_detail". Setelah ditambahkan, sales dapat melanjutkan untuk menambah barang lain. Apabila dirasa sudah cukup, maka sales tinggal meng-klik tombol "Selesai". Program akan menampilkan sales order berikutnya. 


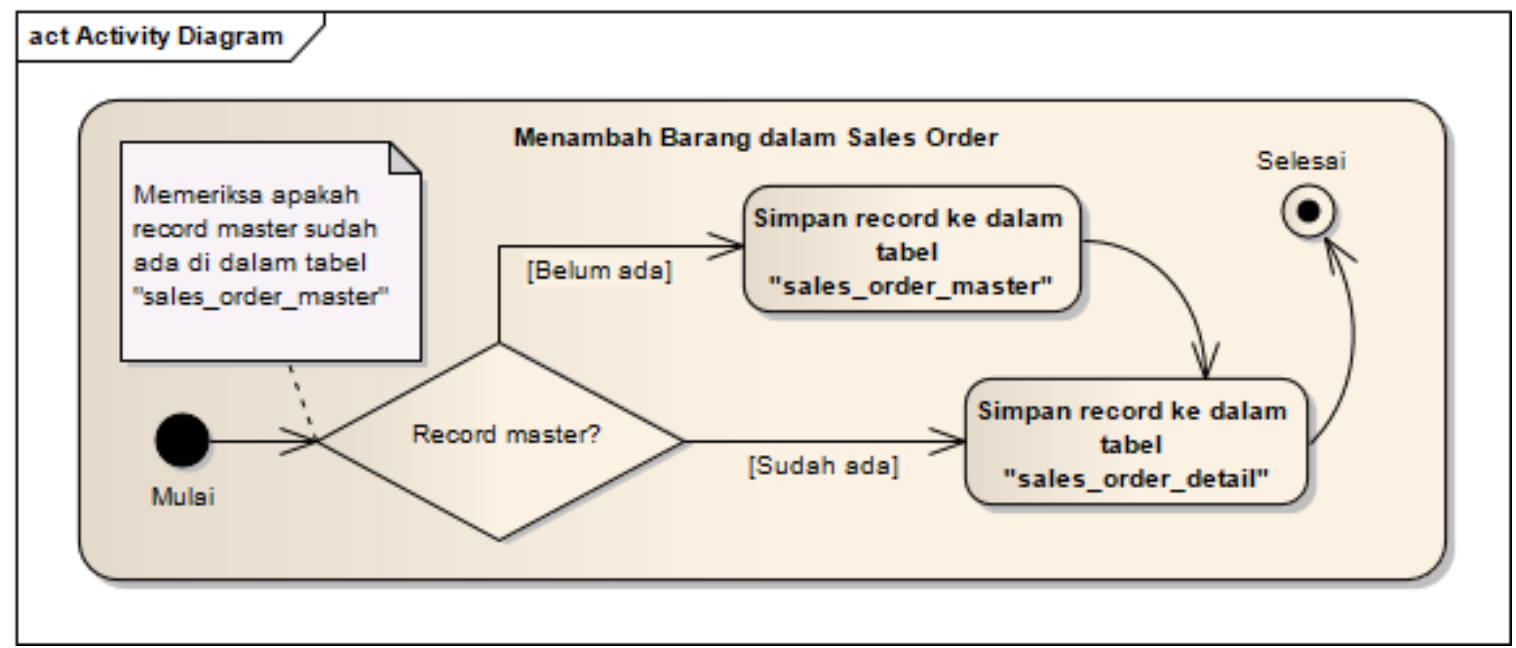

Gambar 8. Activity DiagramMenambah Barang dalam Sales Order.

Proses yang terjadi pada web service ketika sales menekan tombol "Tambah" dapat dilihat pada gambar 8. Gambar tersebut menjelaskan business logic dalam menyimpan data yang dikirim dari smartphone sales. Jadi setelah sales meng-klik tombol "Tambah", data barang sudah langsung dimasukkan ke dalam basis data, tetapi belum memotong stok karena belum merupakan faktur penjualan.

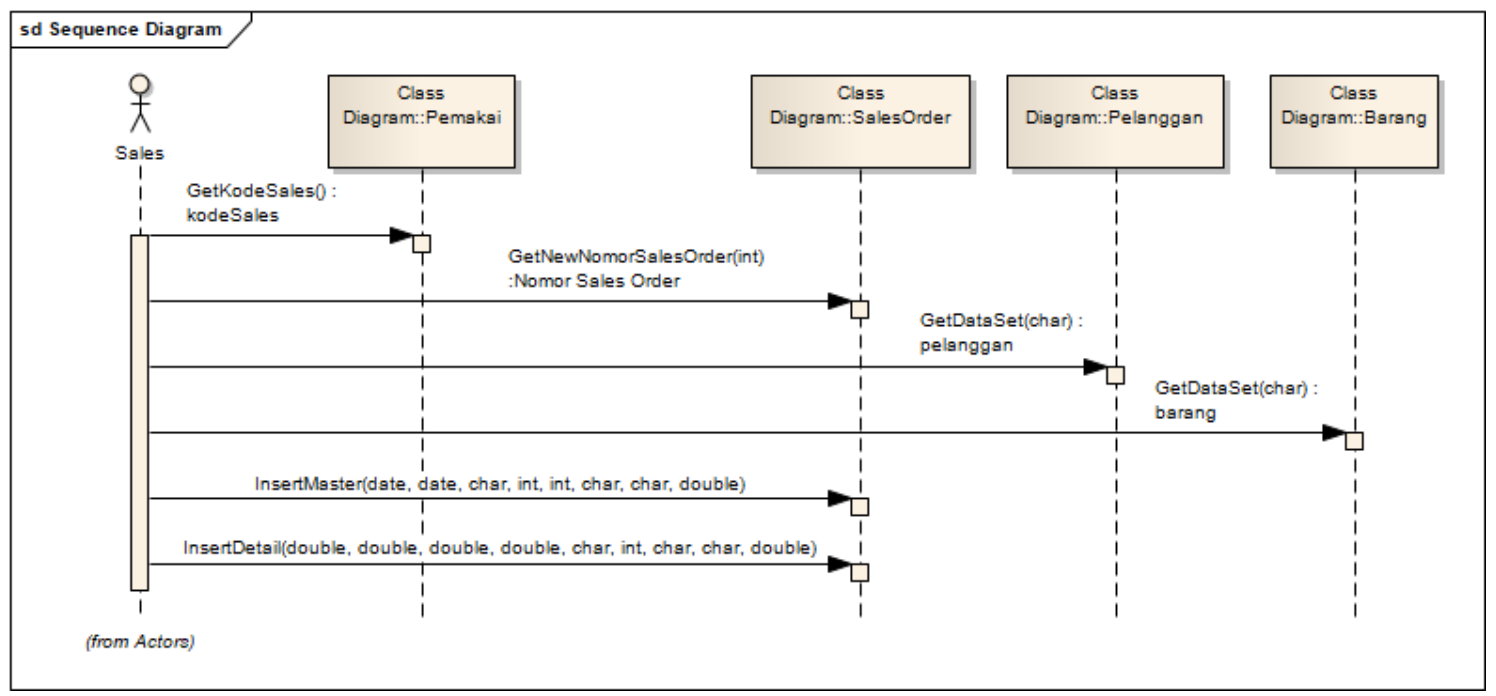

Gambar 9. Sequence Diagram Tambah Sales Order.

Gambar 9 menunjukkan aktivitas yang dilakukan oleh sales untuk menambah sales order. Sequence diagram tersebut juga menunjukkan bahwa proses di web service tidak ada yang panjang, melainkan berupa proses-proses singkat. Hal ini dikarenakan arsitektur web service yang memang dirancang loose-coupled sehingga tidak ada proses yang saling berhubungan. Semua proses berdiri sendiri dan melakukan 1 pekerjaan saja. Ini yang disebut dengan micro-services. Dengan arsitektur seperti ini maka web service mampu melayani sangat banyak permintaan dari client dan fungsi-fungsi yang ada dapat digunakan berulang kali oleh aplikasi yang berbeda. Masing-masing aplikasi dapat membuat logika bisnis sendiri dengan memanfaatkan fungsi-fungsi mikro yang sudah disediakan oleh web service.

Sprint ke-4 merupakan kegiatan menyiapkan koneksi VPN yang menghubungkan PC server di kantor pusat dengan smartphone yang dipegang oleh sales. VPN memanfaatkan jaringan internet publik dengan membuat tunneling sehingga terbentuk sebuah jaringan privat layaknya LAN.Penyedian layanan VPN yang digunakan oleh penulis adalah VPN Telkom. Gambar 10 menunjukkan arsitektur tersebut. TimeBox yang dibutuhkan untuk menyelesaikan Sprint ke-3 adalah 1 minggu. 


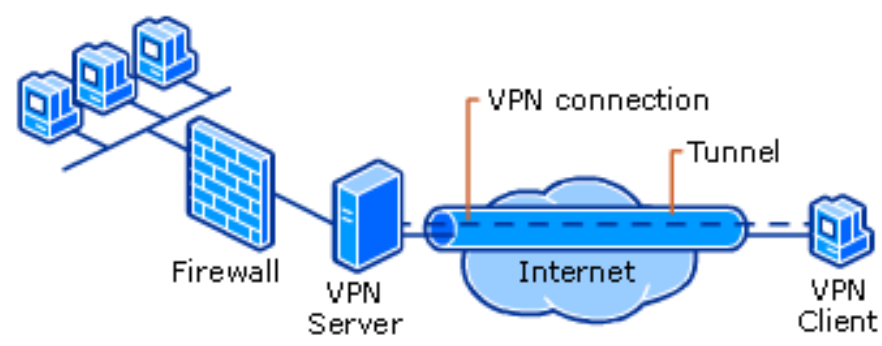

Gambar 10. Arsitektur Virtual Private Network.

Sprint terakhir yaitu Sprint ke-5, merupakan proses penggabungan hasil Sprint ke-1 hingga ke-4 dan dilakukan pengujian. Pengujian sistem dilakukan penulis untuk menguji 2 hal:

1. Yang pertama adalah apakah penerapan metode Scrum berhasil menciptakan sebuah sistem order sales yang sesuai dengan requirement CV. Surya Putra. Penulis menguji dengan membawa smartphone ke kota Singkawang, sementara PC server berada di Pontianak. Jarak kota Pontianak - Singkawang adalah $\pm 150 \mathrm{Km}$. PC server di Pontianak terkoneksi ke jaringan internet IndiHome, sementara smartphone penulis menggunakan jaringan 3G dari Telkomsel.Waktu respon web mobile ini adalah 2-3 detik untuk membuka sebuah halaman web. Demikian juga untuk melakukan proses menyimpan, waktunya adalah sekitar 2-3 detik. Apabila dibandingkan dengan waktu respon jika dikoneksikan langsung ke PC server melalui jaringan WiFi kantor, maka waktu respon tersebut terlambat 1-2 detik. Waktu jeda ini tentunya masih bisa ditoleransi karena tidak terlalu signifikan.

2. Pengujian kedua adalah mengujiseberapa besar dampak yang dirasakan sebelum dan sesudah penerapan sistem order sales pada CV. Surya Putra.

3.

Tabel 1. Dampak Penerapan Sistem Order Sales pada CV. Surya Putra.

\begin{tabular}{|l|l|l|}
\hline Aksi & Sebelum & Sesudah \\
\hline Waktu untuk membuat sales order & $\begin{array}{l}20-30 \text { menit } \\
\text { (tergantung jumlah } \\
\text { record) }\end{array}$ & $5-10$ menit. \\
\hline Omzet & Standar & Meningkat $\pm 10 \%$ \\
\hline
\end{tabular}

Dari tabel 1, terbukti bahwa dengan penerapan Sistem Order Sales mampu menghemat waktu secara signifikan dibandingkan dengan cara manual dengan mencatat di memo kemudian pulang ke kantor dan berkonsultasi dengan admin untuk membuka faktur penjualan. Fakta kedua yang menguatkan adalah sesudah penerapan tersebut, kepercayaan pelanggan semakin meningkat karena waktu pelayanan yang semakin cepat dan adanya penerapan teknologi baru yang terbukti efektif serta meningkatkan prestise CV. Surya Putra sehingga pada akhirnya omzet sales juga meningkat. Dengan meningkatnya omzet sales, secara otomatis juga akan meningkatkan laba perusahaan.

\section{KESIMPULAN}

Berdasarkan hasil dan pembahasan, penulis menyimpulkan bahwa implementasi metodeScrumuntuk menghasilkan sistem order sales memberikan dampak yang positif kepada CV. Surya Putra karena berupa efisiensi waktu yang cukup signifikan. Selain itu dengan penerapan ini juga mampu meningkatkan omzet sales yang pada akhirnya mampu meningkatkan laba perusahaan.

Dengan adanya sistem order sales yang dapat diakse dari mana saja dan kapan saja, dapat meningkatkan produktivitas sales, meningkatkan prestise perusahaan, meningkatkan tingkat kepercayaan pelanggan, dan pada akhirnya dapat meningkatkan omzet sales. Dengan meningkatkan 
beberapa variabel tersebut, maka secara otomatis penelitian ini dapat meningkatkan daya saing dan laba perusahaankhususnya bagi CV. Surya Putra.

\section{SARAN}

Sistem order sales memerlukan penambahan fitur supaya menjadi semakin lengkap. Oleh karena itu penulis menyarankan supaya pada penelitian selanjutnya dapat dikembangkan fitur lain seperti pengecekan stok, dan setoran piutang pelanggan. Selain itu, dengan kombinasi teknologi web service, VPN, dan web mobile, dapat dikembangkan pula web mobile untuk manager yang memiliki fitur seperti pemantauan pencapaian omzet sales, penjualan harian, hingga laporan laba-rugi kotor. Untuk itu penulis menyarankan supaya penelitian ini bisa menjadi pondasi bagi penulis lain supaya penelitian berikutnya menghasilkan sistem yang semakin sempurna.

\section{DAFTAR PUSTAKA}

[1] Indonesia Raksasa Teknologi Digital Asia, Kementerian Komunikasi dan Informatika (Online), (https://www.kominfo.go.id/content/detail/6095/indonesia-raksasa-teknologi-digitalasia/0/sorotan_media, diakses tanggal 18 Agustus 2017)

[2] Liyanage, M., Ylianttila, M., \& Gurtov, A. (2014).IP-based virtual private network implementations in future cellular networks (Online), Handbook of Research on Progressive Trends in Wireless Communications and Networking, DOI: 10.4018/978-1-4666-5170-8.ch003, Halaman 46.

[3] Santana, L. F., Santos, L. F. C. D., Silva, T. S. C., Villar, V. B., Rocha, F. G., \& Gonçalves, V. (2017). Scrum as a Platform to Manage Students in Projects of Technological Development and Scientific Initiation: A Study Case Realized at UNIT/SE (Online), Journal of Information Systems Engineering \& Management, DOI: 10.20897/jisem.201707, ISSN: 2468-4376, Volume 2, Issue 2, 2017, Halaman 1.

[4] N., Dr. Rajkumar, J., Selvakumar, B., Ranjith Babu, Extended Scrum Method ofAgile Practice for Small Scale Project Development (Online), International Journal of Innovative Research in Science, Engineering and Technology, ISSN (Online): 2319-8753, Vol 3, Special Issue 1, 2014, Hal 374.

[5] Microsoft Visual Studio, Wikipedia (Online), (https://en.wikipedia.org/wiki/Microsoft Visual Studio, diakses tanggal 05September 2017).

[6] What is Windows Communication Foundation | Microsoft Docs (Online), (https://docs.microsoft.com/en-us/dotnet/framework/wcf/whats-wcf, diakses 06 September 2017)

[7] Sukerti, Ni Kadek, Pratami, Ni Wayan Cahya Ayu, Implementasi Sistem Informasi Reservasi Speedboat Berbasis Web Service dan SMS Reply (Online), Jurnal Sistem dan Informatika (STIKOM Bali), ISSN: 2460-3792, Vol 9, No 1, 2014, Hal 10.

[8] MySQL :: About MySQL (Online), (https://www.mysql.com/about/, diakses 05September 2017).

[9] MySQL :: MySQL Workbench (Online), (https://www.mysql.com/products/workbench/, diakses 06 September 2017).

[10] Ajax (programming) - Wikipedia (Online),_https://en.wikipedia.org/wiki/Ajax_(programming), diakses 08 September 2017) 